\title{
Citocininas na multiplicação in vitro de hortelã-pimenta (Mentha x Piperita L.)
}

\author{
ASMAR, S. A. ${ }^{* 1}$; RESENDE, R. F. ${ }^{1}$; ARARUNA, E. C. ${ }^{1}$; MORAIS, T. P. ${ }^{1}$; LUZ, J. M. Q. ${ }^{1}$ \\ ${ }^{1}$ Universidade Federal de Uberlândia - UFU, Instituto de Ciências Agrárias, Campus Umuarama, Av. Amazonas s/ \\ n, CEP38400-902, Uberlândia-MG, Brasil. siasmar@yahoo.com.br
}

\begin{abstract}
RESUMO: O hortelã-pimenta é um hibrido triplo, Menthax piperita, utilizado de forma medicinal no tratamento de náuseas, cólicas gastrointestinais, flatulências, cálculos biliares, icterícia, ansiedade, expectoração e expulsão de vermes intestinais. Na micropropagação, o BAP (6benzilaminopurina) e KIN (cinetina) têm sido as fontes de citocininas mais empregadas. O objetivo deste trabalho foi avaliar o efeito de reguladores vegetais na multiplicação in vitro de hortelãpimenta. Explantes constituídos de segmentos nodais provenientes de plântulas já estabelecidas in vitro com aproximadamente $0,5 \mathrm{~cm}$ foram inoculados em meio $\mathrm{MS}$, suplementado com diferentes associações de BAP e KIN, em adição de $30 \mathrm{~g} \mathrm{~L}^{-1}$ de sacarose. As concentrações de citocininas utilizadas foram 0,0; 1,0 e 2,0 $\mathrm{mg} \mathrm{L}^{-1}$ de BAP e 0,0; 0,5 e 1,0 $\mathrm{mg} \mathrm{L}^{-1}$ de KIN. O delineamento experimental foi o inteiramente casualizado, com nove tratamentos consistindo de cinco frascos cada um, sendo que cada frasco continha quatro explantes. A utilização de $2,0 \mathrm{mg} \mathrm{L}^{-1}$ de BAP promove a multiplicação in vitro de hortelã-pimenta, porém, diminui o índice de sobrevivência. $O$ uso de citocininas aumenta a massa fresca e seca dos explantes e a ausência destes reguladores propicia o alongamento nesta espécie.
\end{abstract}

Palavras-chave: Mentha x Piperita L., cultura de tecidos, regulador de crescimento

ABSTRACT: Cytokinins on in vitro multiplication of peppermint (Mentha x Piperita L.). Peppermint is used for medical treatments of nausea, gastrointestinal cramps, flatulence, gallstones, jaundice, anxiety, sputum and expulsion of intestinal worms. In micropropagation, BAP (6-benzylaminopurine) and KIN (kinetin) have been the most widely used sources of cytokinins. The aim of this study was to evaluate the effect of plant growth regulators in multiplication of peppermint. Explants consisting of nodal segments from seedlings already established in vitro with approximately $0,5 \mathrm{~cm}$ were inoculated on MS medium supplemented with different combinations of BAP and KIN and $30 \mathrm{~g} \mathrm{~L}^{-1}$ of sucrose. The concentrations of cytokinins used were 0,$0 ; 1,0$ and $2,0 \mathrm{mg} \mathrm{L}^{-1}$ of BAP and 0,$0 ; 0,5$ and $1,0 \mathrm{mg} \mathrm{L}^{-1}$ of KIN. The experiment was set up in a completely randomized design with nine treatments consisting of five bottles each, and each vial contained four explants. The use of $2,0 \mathrm{mg} \mathrm{L}^{-1}$ of BAP promotes the in vitro multiplication of peppermint, but decreases the survival rate. Cytokinins increase fresh and dry weight of explants and the absence of these regulators provides the elongation in this specie.

Key words: Menthax piperita L., tissue culture, growth regulator

\section{INTRODUÇÃO}

Mentha piperita L. é uma planta conhecida como hortelã-pimenta, menta ou hortelã-apimentada, pertencente à família Labiatae. Seu uso medicinal é recomendado para o tratamento de náuseas, cólicas gastrointestinais, flatulências, cálculos biliares, icterícia, ansiedade, expectoração e expulsão de vermes intestinais. As propriedades medicinais desta planta estão relacionadas com o óleo essencial extraído de suas folhas frescas (Lorenzi \& Matos,
2002; Corrêa et al., 2003).

Sua propagação pode ser sexuada ou vegetativa. No entanto, a multiplicação via sementes é laboriosa. De acordo com Veronese et al. (2001), 18000 botões florais de hortelã-pimenta contendo mais de 2,75 milhões de óvulos desenvolveram apenas 6 sementes viáveis. Ainda, a variabilidade genética decorrente da multiplicação via sementes pode comprometer o uso desta espécie para propósitos

Recebido para publicação: agosto de 2011

Aceito para publicação: dezembro de 2011

Rev. Bras. PI. Med., Botucatu, v.13, especial, p.533-538, 2011. 
farmacêuticos, devido a variações na composição química do óleo extraído. Por outro lado, a propagação assexuada do hortelã-pimenta pode permitir o acúmulo de fungos sistêmicos, bactérias e infecções virais que prejudicam a produção desta espécie.

Neste contexto, a cultura de células e de tecidos pode resolver ou minimizar pontos críticos na multiplicação sistematizada de plantas com propriedades medicinais e ou produtoras de Óleos essenciais pelo processo de micropropagação. Muitas referências da aplicação desta técnica em hortelã-pimenta são encontradas na literatura (Paolicchi et al., 2002; Ghanti et al., 2004; Sunandakumari et al., 2004; Wang et al., 2008).

Um dos principais fatores que interferem na propagação in vitro é a suplementação do meio de cultivo com reguladores de crescimento. $\mathrm{Na}$ micropropagação, o BAP (6-benzilaminopurina) e KIN (cinetina) têm sido as fontes de citocininas mais utilizadas (Nagori \& Purohit, 2004), pois são fitohormônios associados ao crescimento e desenvolvimento das plantas, participando no controle da divisão celular. As citocininas estimulam o crescimento pela expansão mais que pelo alongamento (Stoynova et al., 2004) e, em plantas aromáticas, também vêm sendo utilizadas para maximizar a biomassa e a produção de óleos essenciais (Stoeva \& Iliev, 1997).

O objetivo deste trabalho foi avaliar o efeito de reguladores vegetais na multiplicação in vitro de hortelã-pimenta, utilizando-se diferentes concentrações de BAP e KIN.

\section{MATERIAL E MÉTODO}

O trabalho foi realizado no Laboratório de Biotecnologia da Universidade Federal de Uberlândia. Explantes constituídos de segmentos nodais provenientes de plântulas já estabelecidas in vitro com aproximadamente $0,5 \mathrm{~cm}$ foram inoculados em meio
MS (Murashige \& Skoog, 1962), suplementado com diferentes associações de BAP e KIN, em adição de $30 \mathrm{~g} \mathrm{~L}^{-1}$ de sacarose. As concentrações de citocininas utilizadas foram 0,$0 ; 1,0$ e 2,0 $\mathrm{mg} \mathrm{L}^{-1}$ de BAP e 0,0; 0,5 e $1,0 \mathrm{mg} \mathrm{L}^{-1}$ de KIN.

$\mathrm{O} \mathrm{pH}$ do meio de cultura foi ajustado para 5,8 e em seguida autoclavado a $121^{\circ} \mathrm{C}$ e $1,2 \mathrm{~atm}$ durante 20 minutos. Posteriormente em câmara de fluxo laminar, os explantes foram inoculados em frascos de $200 \mathrm{~mL}$, contendo $30 \mathrm{~mL}$ do meio de cultivo MS. Os frascos foram vedados com tampas de polipropileno e mantidos em sala de crescimento convencional, com fotoperíodo de 16 horas, temperatura de $25 \pm 2^{\circ} \mathrm{C}$, com intensidade de $52,5 \mathrm{~W}$ $\mathrm{m}^{-2} \mathrm{~s}^{-1}$, fornecida por lâmpadas brancas fluorescentes.

O delineamento experimental foi 0 inteiramente casualizado, com nove tratamentos consistindo de 5 frascos cada um, sendo que cada frasco continha 4 explantes. Os dados obtidos foram submetidos à análise de variância utilizando-se 0 programa estatístico Sisvar 4.3 (Ferreira, 2000), utilizando-se o teste de regressão, a $5 \%$ de probabilidade.

Após 30 dias foram avaliadas as seguintes características: índice de sobrevivência (número de explantes desenvolvidos por número de explantes inoculados), número, comprimento, massa fresca e seca das brotações desenvolvidas.

\section{RESULTADO E DISCUSSÃO}

O índice de sobrevivência e o número de brotos por explante foram significativamente influenciados apenas pelas concentrações de BAP (Tabela 1). Porém, os tratamentos que apresentaram ausência desta citocinina ou sua menor dose $(1,0$ $\mathrm{mg} \mathrm{L}^{-1}$ ), tiveram $100 \%$ de sobrevivência. A menor taxa de sobrevivência $(95,8 \%)$ foi verificada no tratamento com BAP a 2,0 $\mathrm{mg} \mathrm{L}^{-1}$ (Figura 1).

Por outro lado, o aumento da concentração

TABELA1. Análise de variância para as características avaliadas em plântulas de hortelã-pimenta cultivadas em diferentes concentrações de BAP e KIN (mg L-1).

\begin{tabular}{|c|c|c|c|c|c|}
\hline $\begin{array}{l}\text { FONTE DE } \\
\text { VARIAÇÃO }\end{array}$ & $\begin{array}{c}\text { Índice de } \\
\text { sobrevivência } \\
\text { (Pr>Fc) }\end{array}$ & $\begin{array}{l}\text { Número de } \\
\text { brotos } \\
(\mathrm{Pr}>\mathrm{Fc})\end{array}$ & $\begin{array}{l}\text { Comprimento } \\
\text { dos brotos } \\
(\mathrm{Pr}>\mathrm{Fc})\end{array}$ & $\begin{array}{l}\text { Massa } \\
\text { fresca } \\
(\mathrm{Pr}>\mathrm{Fc})\end{array}$ & $\begin{array}{c}\text { Massa seca } \\
(\mathrm{Pr}>\mathrm{Fc})\end{array}$ \\
\hline BAP & $0,0470^{*}$ & $0,0007^{*}$ & $0,0001^{*}$ & $0,0001^{*}$ & $0,0000^{*}$ \\
\hline KIN & $0,4428^{\mathrm{NS}}$ & $0,1795^{\mathrm{NS}}$ & $0,0103^{*}$ & $0,0009^{*}$ & $0,0000^{*}$ \\
\hline $\mathrm{BAP} \times \mathrm{KIN}$ & $0,5130^{\mathrm{NS}}$ & $0,1362^{\mathrm{NS}}$ & $0,0960^{\mathrm{NS}}$ & $0,5802^{\mathrm{NS}}$ & $0,4871^{\mathrm{NS}}$ \\
\hline CV (\%) & 5,17 & 20,33 & 23,94 & 31,18 & 30,68 \\
\hline
\end{tabular}

${ }^{*}$ significativo a $5 \%$ de probabilidade, ${ }^{N S}$ não significativo

Rev. Bras. Pl. Med., Botucatu, v.13, especial, p.533-538, 2011. 


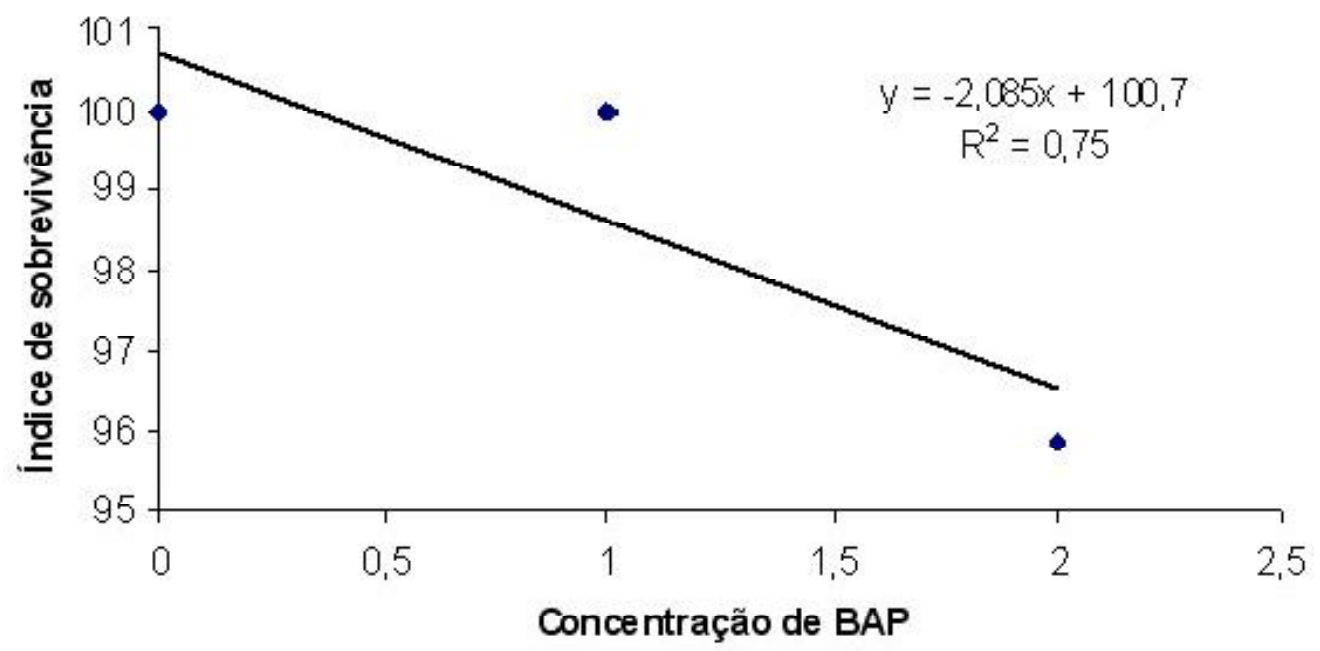

FIGURA 1. Índice de sobrevivência (\%) em plântulas de hortelã-pimenta cultivadas em diferentes concentrações de BAP (mg L-1). Os valores são médias de cinco repetições. Universidade Federal de Uberlândia, 2011.

de BAP estimulou a multibrotação, sendo que maior número de brotos $(5,75)$ foi encontrado na maior concentração utilizada (2,0 $\left.\mathrm{mg} \mathrm{L}^{-1}\right)$ (Figura 2). Isto ocorre uma vez que esta citocinina é capaz de promover a quebra da dominância apical e da dormência das gemas laterais culminando, assim, com a formação de novos brotos (George, 1993). Brotações múltiplas no gênero Mentha também têm sido reportadas a partir de calos derivados de embriões maduros e imaturos e de folhas, em meio MS suplementado com BAP+ANA (ácido naftalenoacético) ou somente com BAP (Van Eck \& Kitto, 1990; 1992).

O resultado deste trabalho também corrobora com o encontrado em estudos de micropropagação de outras plantas medicinais, nos quais maiores taxas de multiplicação de chapéu-de-couro
(Echinodorus cf. scaber Rataj) (Pereira et al., 2000) e poejo do campo (Cunila galioides Benth.) foram observadas apenas com a adição de BAP ao meio de cultura (Fracaro \& Echeverrigaray, 2001).

O comprimento, a massa fresca e seca dos brotos foram estimulados pelas concentrações de BAP e de KIN, porém, não houve interação entre estes dois fatores para estas variáveis (Tabela 1). Maior comprimento de brotos foi obtido na ausência de BAP $(7,05 \mathrm{~cm})$ (Figura 3), como também na ausência de KIN (6,36 cm) (Figura 4). Skala \& Wysokinska (2004) e Garlet et al. (2011) também observaram redução no alongamento de plantas de Salvia nemorosa L. e de Mentha x gracilis Sole, respectivamente, durante a proliferação in vitro destas espécies com o aumento da concentração de BAP. Pasqual (2001) relata que elevadas concentrações de citocininas podem reduzir

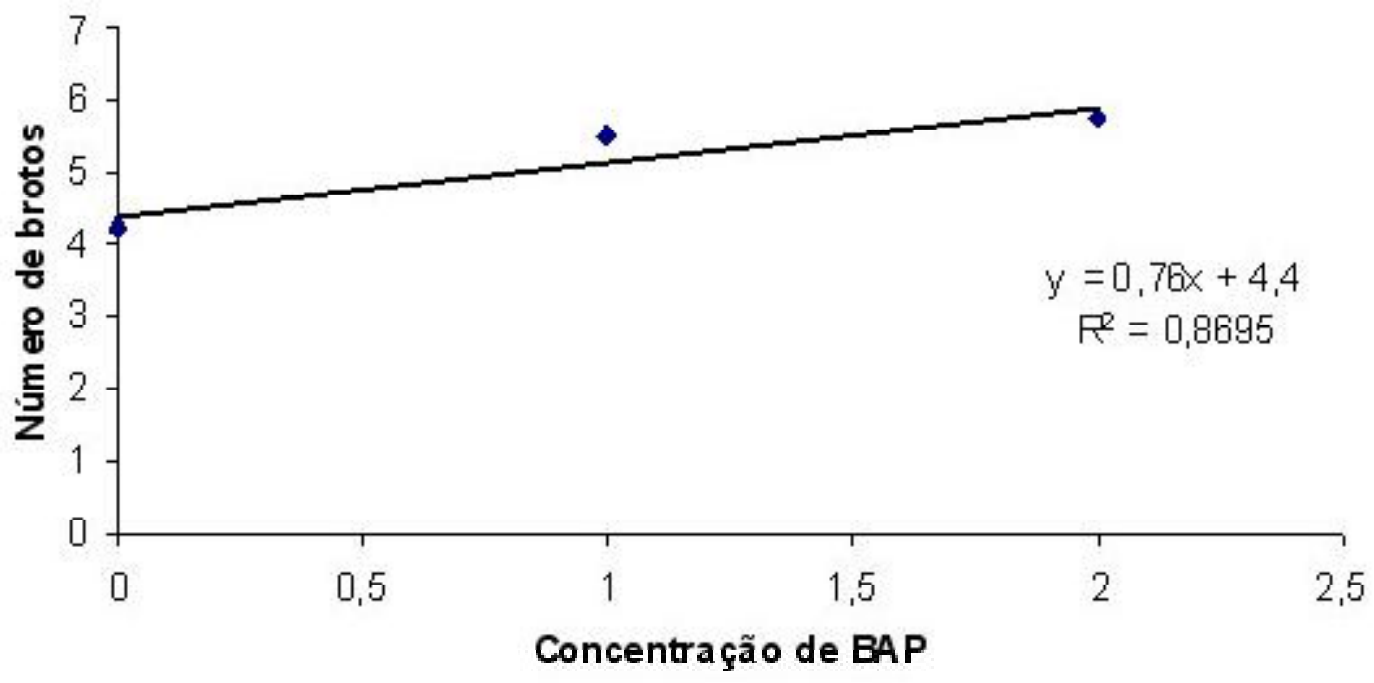

FIGURA 2. Número de brotos em plântulas de hortelã-pimenta cultivadas em diferentes concentrações de BAP (mg L-1). Os valores são média de cinco repetições. Universidade Federal de Uberlândia, 2011. 


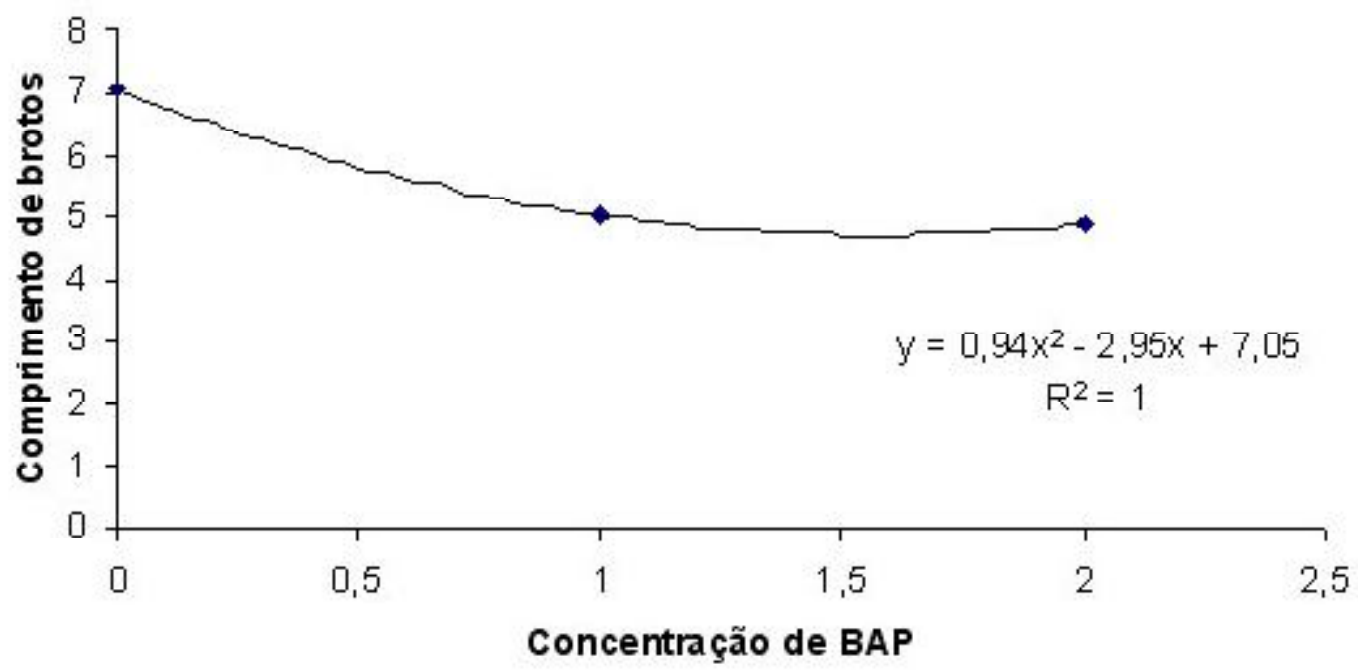

FIGURA 3. Comprimento de brotos (cm) de plântulas de hortelã-pimenta cultivadas em diferentes concentrações de BAP ( $\left.\mathrm{mg} \mathrm{L}^{-1}\right)$. Os valores são médias de cinco repetições. Universidade Federal de Uberlândia, 2011.

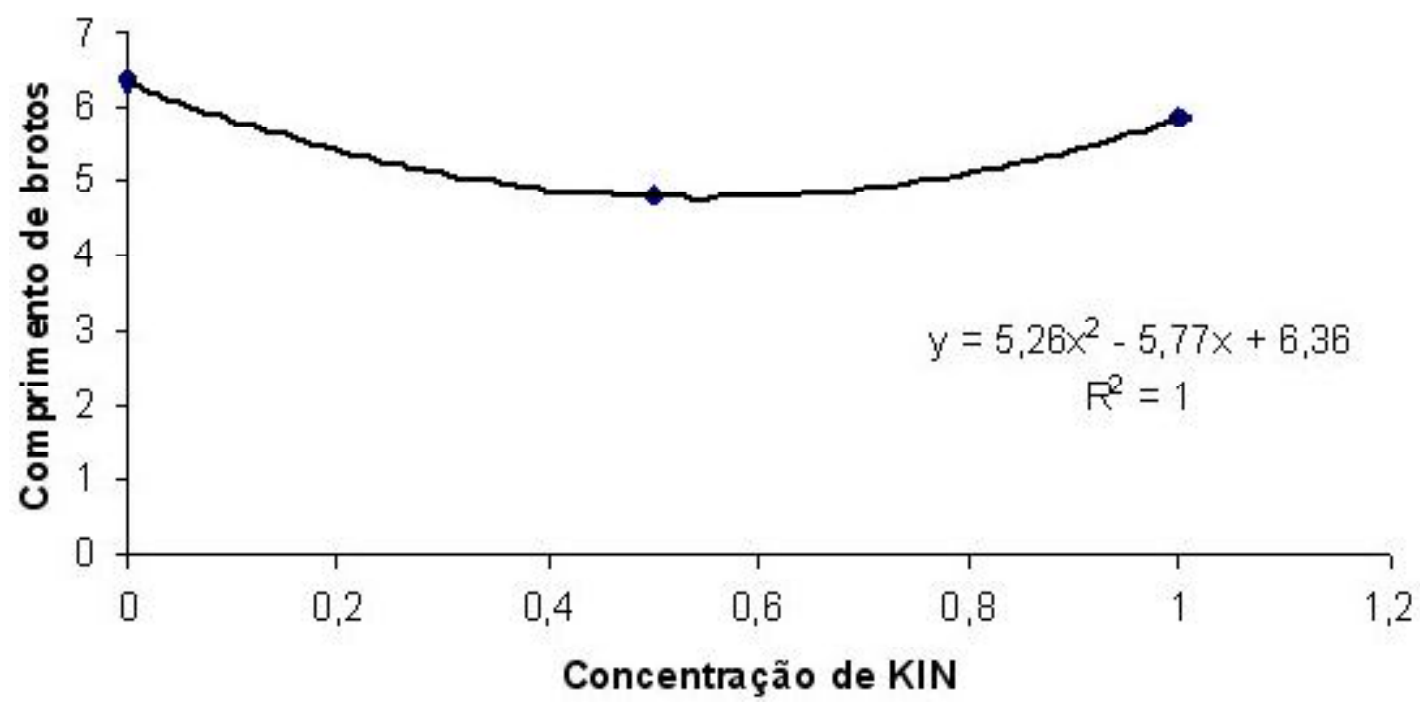

FIGURA 4. Comprimento de brotos (cm) de plântulas de hortelã-pimenta cultivadas em diferentes concentrações de KIN (mg L-1). Os valores são médias de cinco repetições. Universidade Federal de Uberlândia, 2011.

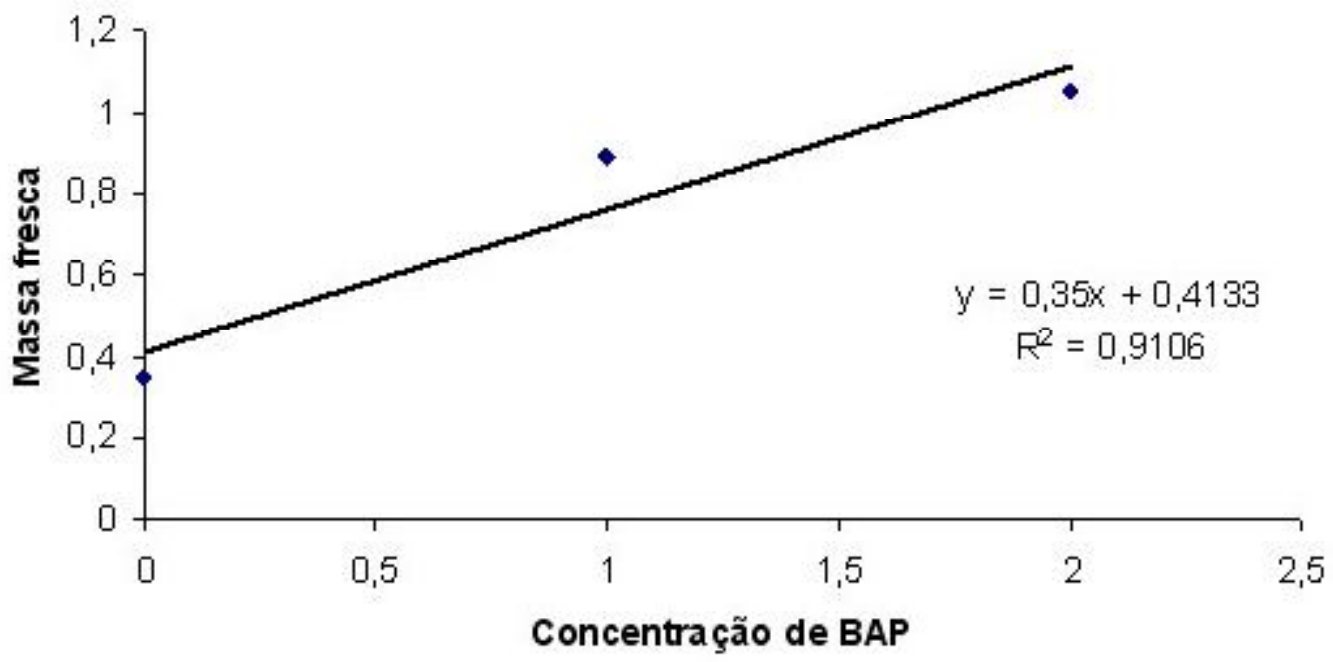

FIGURA 5. Massa fresca (g) de plântulas de hortelã-pimenta cultivadas em diferentes concentrações de BAP (mg $\mathrm{L}^{-1}$ ). Os valores são médias de cinco repetições Universidade Federal de Uberlândia, 2011. 


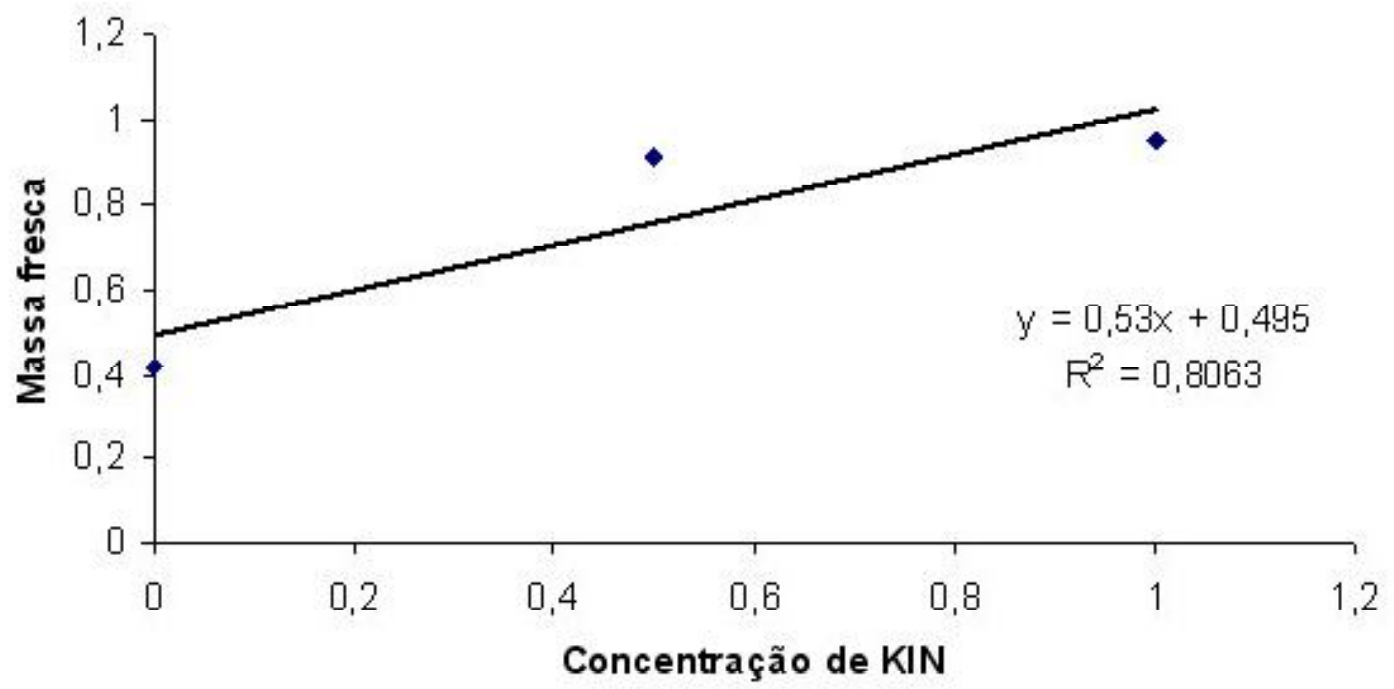

FIGURA 6. Massa fresca (g) de plântulas de hortelã-pimenta cultivadas em diferentes concentrações de KIN (mg $\mathrm{L}^{-1}$ ). Os valores são médias de cinco repetições Universidade Federal de Uberlândia, 2011.

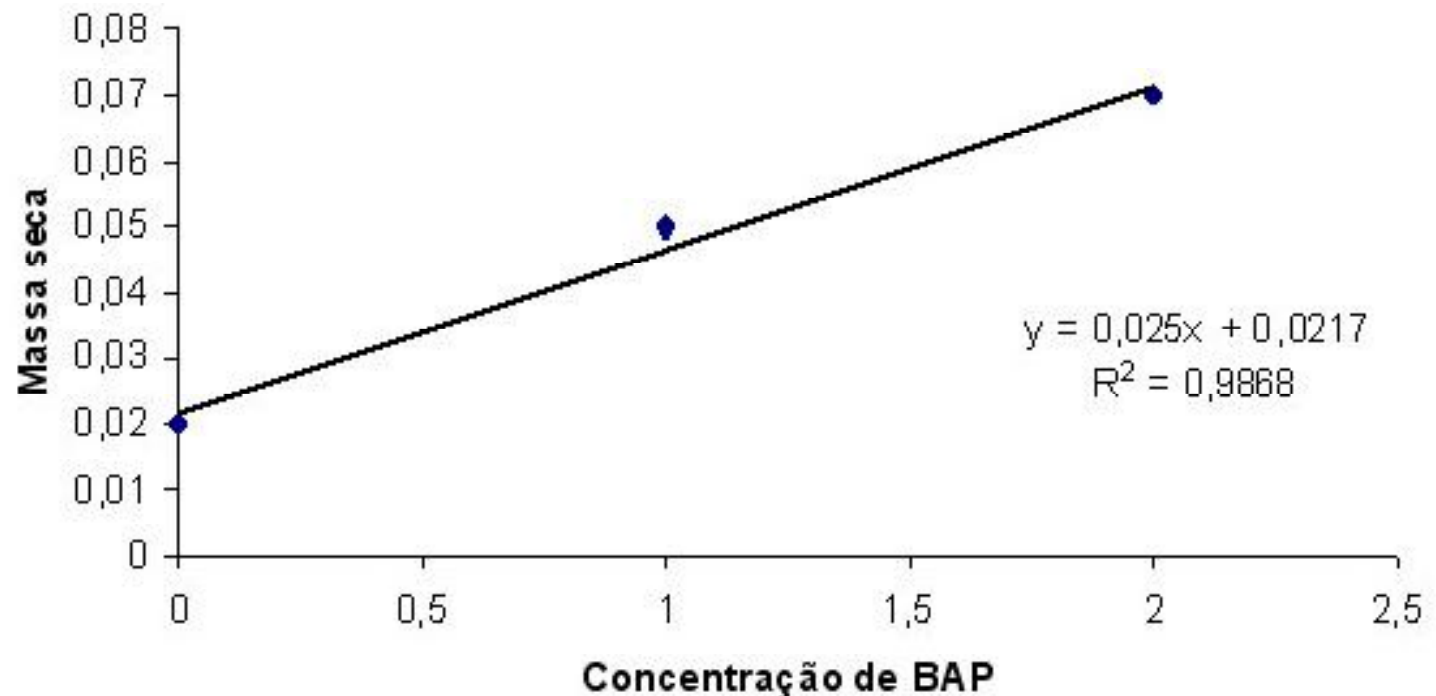

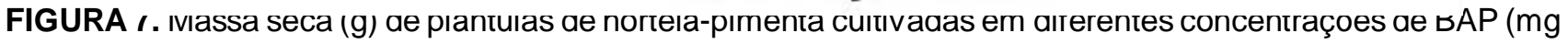
L-1 $^{-1}$. Os valores são médias de cinco repetições Universidade Federal de Uberlândia, 2011.

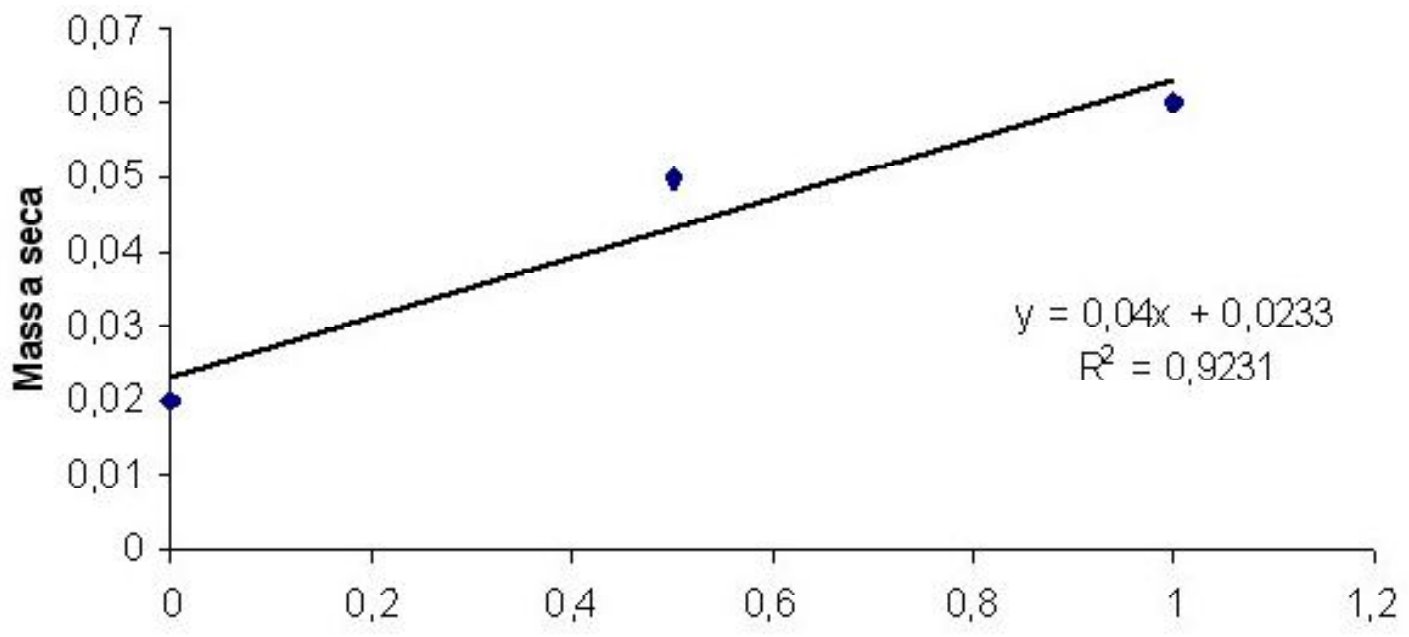

Concentração de KIN

Figura 8. Massa seca (g) de plântulas de hortelã-pimenta cultivadas em diferentes concentrações de KIN (mg L1). Os valores são médias de cinco repetições Universidade Federal de Uberlândia, 2011. 
o tamanho das brotações. Diante disto, pode-se inferir que concentrações mais elevadas de citocininas, principalmente o BAP, são eficientes para o aumento do número de novos brotos, enquanto que, contrariamente, concentrações mais baixas ou a ausência deste regulador promovem o alongamento do explante.

As massas fresca e seca aumentaram linearmente à medida que as concentrações de BAP e KIN eram adicionadas ao meio de cultivo. A melhor resposta encontrada para massa fresca foi quando se utilizou 2,0 $\mathrm{mg} \mathrm{L}^{-1}$ de BAP (Figura 5) e 1,0 $\mathrm{mg} \mathrm{L}^{-}$

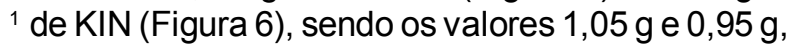
respectivamente. Com o aumento da massa fresca no decorrer do tempo, o potencial osmótico do meio fica maior. Consequentemente, as plantas nesse meio conseguem absorver mais água para os seus tecidos e adquirem maior massa fresca (Villa et al., 2005). Comportamento oposto, no entanto, foi encontrado por Dutra et al. (2004) em trabalho de multiplicação in vitro de oliveira (Olea europaea L.), no qual à medida em que aumentou a concentração de BAP, houve redução nessa variável.

Para massa seca, os melhores resultados encontrados também foram nas maiores concentrações de citocininas, e os valores obtidos foram de $0,07 \mathrm{~g}$ com a utilização de BAP (Figura 7) e de 0,06 g utilizando-se KIN (Figura 8).

Com esse estudo, pode-se concluir que a utilização de $2,0 \mathrm{mg} \mathrm{L}^{-1}$ de BAP promove a multiplicação in vitro de hortelã-pimenta, porém, diminui o índice de sobrevivência. O uso de citocininas aumenta a massa fresca e seca dos explantes, e a ausência destes reguladores propicia o alongamento nesta espécie.

\section{AGRADECIMENTO}

Os autores agradecem à Fundação de Amparo à Pesquisa do Estado de Minas Gerais (FAPEMIG), pelo apoio financeiro, ao Conselho Nacional de Desenvolvimento Científico e Tecnológico (CNPq), pela concessão de bolsa ao primeiro autor e, ao PET-SESU pela concessão de bolsas aos demais autores.

\section{REFERÊNCIA}

CORRÊA, A.D. et al. Plantas medicinais: do cultivo à terapêutica. 6 ed. Petrópolis: Bozes, 2003. 247p.

DUTRA, L.F. et al. Comunicação: Multiplicação in vitro de oliveira (Olea europaea L.). Ciência e Agrotecnologia, v.28, n.1, p.220-223, 2004.

FERREIRA, D.F. Sisvar 4.3: sistema de análises de variância para dados balanceados: programa de análises estatísticas e planejamento de experimentos. Lavras: UFLA/DEX, 2000.
FRACARO, F.; ECHEVERRIGARAY, S. Micropropagation of Cunila galioides, a popular medicinal plant of south Brazil. Plant Cell, Tissue and Organ Culture, v.64, n.1, p.1-4, 2001.

GARLET, T.M.B. et al. Influência de citocininas na micropropagação de Mentha x gracilis Sole. Revista Brasileira de Plantas Medicinais, v.13, n.1, p.30-34, 2011. GEORGE, E.F. Plant propagation by tissue culture: the technology. 1.ed. Dordrecht: Springer, 1993. 574p.

GHANTI, K. et al. Rapid regeneration of Mentha piperita L. from shoot tip and nodal explants. Indian Journal of Biotechnology, v.3, p.594-598, 2004.

LORENZI, H.; MATOS, F.J.A. Plantas medicinais no Brasil: nativas e exóticas. Nova Odessa: Plantarum, 2002. 512p.

MURASHIGE, T.; SKOOG, F. A revised medium for rapid growth and bioassays with tobacco tissue cultures. Physiologia Plantarum, v.15, n.3, p.473-497, 1962.

NAGORI, R.; PUROHIT, S.D. In vitro plantlet regeneration in Annona squamosa L. through direct shoot bud differentiation on hypocotyl segments. Scientia Horticulturae, v.99, n.1, p.89-98, 2004.

PAOLICCHI, F. et al. Effect of clinorotation on in vitro cultured explants of Mentha piperita L. Scientia Horticulturae, v.92, n.3-4, p.305-315, 2002.

PASQUAL, M. Textos acadêmicos: meios de cultura. Lavras: FAEPE/UFLA, 2001. 127p.

PEREIRA, F.D. et al. Propagação in vitro de chapéu-decouro (Echinodorus cf. scaber Rataj), uma planta medicinal. Ciência e Agrotecnologia, v.24, p.74-80, 2000. SKALA, E.; WYSOKINSKA, H. In vitro regeneration of Salvia nemorosa L., from shoot tips and leaf explants. In Vitro Cellular \& Developmental Biology - Plant, v.40, p.596-692, 2004.

STOEVA, T.; ILIEV, I. Influence of some phenylurea cytokinins on spearmint essential oil composition. Bulgarian Journal of Plant Physiology, v.23, n.3-4, p.6671, 1997.

STOYNOVA, B.E. et al. Cell division and cell expansion in cotyledons of arabidopsis seedlings. New Physiologist, v.162, p.471, 2004.

SUNANDAKUMARI, C. et al. Rapid axillary bud proliferation and ex vitro rooting of herbal spice, Mentha piperita L. Indian Journal of Biotechnology, v.3, p.108112, 2004.

VAN ECKE, J.M.; KITTO, S.L. Callus initiation and regeneration in Mentha. Horticultural Science, v.25, p.804-806, 1990.

VAN ECKE, J.M.; KITTO, S.L. Regeneration of peppermint and orange mint from leaf disks. Plant Cell, Tissue and Organ Culture, v.30, p.41-46, 1992.

VERONESE, P. et al. Bioengineering mint crop improvement. Plant Cell, Tissue and Organ Culture, v.64, p.133-144, 2001.

VILLA, F. et al. Multiplicação in vitro da amoreira-preta 'ÉBANO' em diferentes concentrações de meio MS e BAP. Ciência e Agrotecnologia, v.29, n.3, p.582-589, 2005. WANG, $X$. et al. Highly efficient in vitro adventitious shoot regeneration of peppermint (Mentha $\mathrm{x}$ piperita L.) using internodal explants. In Vitro Cellular \& Developmental Biology - Plant, on line first, 2008. Disponível em: <http://www.sjziam.ac.cn/sjziam/medial/ 2008/08pdf/20081204-wangxiaohuan.pdf>. Acesso em: ago. 2011. doi 10.1007/s11627-008-9170-x.

Rev. Bras. PI. Med., Botucatu, v.13, especial, p.533-538, 2011. 